\title{
THE EDICT OF DIOCLETIAN, ARIA AND CASHMERE
}

\author{
John Peter Wild \\ University of Manchester
}

\begin{abstract}
The article examines the types of animal fibre listed in Chapter XXV 'On Wool' in Diocletian's Edict on Maximum Prices (AD 301). Wool from the leading sheep-rearing regions, the fibres from the mussel pinna nobilis, wool from rabbit or hare and -more controversially- 'cashmere' from 'Aria' all figure in Chapter XXV and are considered here from an archaeological perspective.
\end{abstract}

Key words: Wool. Pinna nobilis. Rabbit hair. Cashmere.

\section{El edicto de Diocleciano, Aria y cachemira}

Resumen: El artículo examina los tipos de fibra animal enumerados en el Capítulo XXV 'Sobre la lana' en el Edicto sobre Precios Máximos (301 d.C.) de Diocleciano. La lana de las regiones destacadas en la cría de oveja, las fibras del mejillón pinna nobilis, lana de conejo o liebre y -más controvertidamente- 'cachemira' de 'Aria' figuran todas ellas en el Capítulo XXV y son consideradas aquí desde una perspectiva arqueológica.

Palabras clave: Lana. Pinna nobilis. Pelo de conejo. Cachemira.

In 1984 a magisterial study of prehistoric and Roman textile production in the Iberian peninsula arrived in my post. It was by an author whose name was not familiar to me -Carmen Alfaro Giner- but the name and personality rapidly became familiar as correspondence between us developed, and Carmen was drawn into the circle of historians, archaeologists and conservators associated with the North-European Symposium for Archaeological Textiles. She was soon thinking of establishing a southern equivalent, which she founded formally in 2002 as Purpureae Vestes and ran almost single-handedly thereafter. She subsequently edited and published through the University of Valencia an important series of volumes arising from its colloquia in Spain, Greece and Italy. The paper below is offered to Carmen in gratitude, great affection and huge admiration for all she has achieved in promoting the study of ancient textiles.

My argument begins with the document conventionally known as the Edictum Diocletiani de pretiis rerum venalium, Diocletian's Edict 'on the (maximum) prices of things on the market'. Arguably it is the most important single written source for the study of clothing and textiles in the Roman world (for text see Lauffer, 1971; Giacchero, 1974; for discussion of purpose see Meissner, 2000; Brandt, 2004). Promulgated late in AD 301 (Corcoran, 1996, 206), it was an ambitious, but ultimately failed, attempt to stem the inflation of prices for consumer goods and services which Diocletian claims in his lengthy preamble was disastrously eroding the purchasing power of his soldiers (Lauffer, 1971, 90-97; Corcoran, 1996, 207-213).

The text has been recovered from fragments of varying size from a set of supposedly

Data de recepció: 19 de novembre de 2014 / Data d'acceptació: 9 de desembre de 2014. 
identical inscriptions which were posted for public display in the central spaces of cities, such as Aphrodisias in Caria (Reynolds, 1989, 265; Crawford, 2002, 157-162). Here, columns of text were inscribed on the standing façade of the basilica facing the South Agora (but much of it was carved too high up for the casual passer-by to read). The geographical distribution of the forty-four known find-spots of inscribed fragments is confined to Greece, Cyrenaica and certain provinces in Asia Minor, and that suggests that the Edict was enforced principally in the eastern provinces ruled directly by Diocletian as Augustus and Galerius as Caesar, and even then perhaps only where provincial governors had a particular enthusiasm for the document (Corcoran, 1996, 229-323; Crawford, 2002, 156). The Edict's preamble nonetheless asserts that it was issued on the authority of all four Tetrarchs. The legislation was drafted, it has been argued, during Diocletian's threeyear residency (AD 299-301) in Syrian Antioch (Corcoran, 1996, 206); but its compilers had gathered and processed information on an empire-wide basis, and at least for the textile-related chapters, it is hard to detect significant bias (pace Corcoran, 1996, 221-225).

The archetype was in Latin, and copies of the text were engraved in Latin even in the Greek-speaking provinces; but in the province of Achaia, the heart-land of the Greekspeaking world, Greek translations of the commodities and wages list were substituted for the Latin (Lauffer, 1971, 1-2).

For most entries in the Edict a specific figure in denarii is prescribed for each item or service recorded. The pricing structure as a whole, however, has an arbitrary form which betrays the hand of bureaucracy. Nonetheless the prices quoted seem not to be out of touch with reality, a question which has been much debated (Corcoran, 1996, 225-229; Morelli, 2004, 57-62). From our point of view, however, it is the prices relative to one another within the Edict rather than their absolute values which matter; for they reflect the relative qualities of the items listed.

In 1893 when Mommsen and Blümner co-operated in publishing the consolidated text from the then known 37 fragments of the Edict there were significant but unquantifiable gaps in the document as it was available. Since then excavations have brought to light more finds of text, notably the extensive fragments from Aphrodisias (Reynolds, 1989) which were appearing as Lauffer was putting the finishing touches to his edition of the Edict (1971). The fragments from Aezani were known, but not available in a critical edition when Giacchero followed Lauffer into print in 1974 (see now Crawford, Reynolds, $1975 ; 1977 ;$ 1979). Though still lacunose, the overall scheme of the Edict has at last become much clearer, making argumenta ex silentio less risky (for example Morelli, 2004, 66-67, on the missing pallium).

It is apparent that the Edict's compilers distinguished between a textile industry based on wool -more accurately, on animal fibres including silk- and one based on flax. The archaeological evidence, coupled with a wealth of information from other written sources, confirms that they reflected correctly the situation as they found it. They devoted seven chapters or sections of varying length to textiles produced from animal fibres and to the craftspeople and materials integral to the 'woollen' industry, while the linen industry in all its aspects (so far as the text can be reconstructed [Giacchero, 1974, 184207]) is accorded just one long and one short chapter (plus two lines in Chapter XXV on 'wool'). No account was taken by the compilers of the recognised sequence of production stages per se leading from the raw fibres to the finished goods: a comprehensive chapter on wool textiles (XIX) is followed by a chapter stipulating the pay rates of weavers $(\mathrm{XX})$, on payment for preparing raw wool and flax (XXI), on the charges of 
fullers for finishing and cleaning clothing (XXII), on the price of silk yarn and costs of processing it (XXIII), on prices for purple-dyed silk and wool and payment for spinning (XXIV), and finally on the prices for special types of raw wool and animal fibre (XXV). For linens the longer chapter (XXVI in Giacchero's edition) deals in detail with the prices of types of prepared flax fibre, clothing and textile sundries, the shorter Chapter XXVII with the linen textiles which carried tapestry-woven decoration in purple-dyed wool (XXVII) (Giacchero, 1974, 203-207).

The crux which I want to investigate here is to be found in an enigmatic entry at the end of Chapter XXV 'On Wool'; but first the character of that chapter is worth reviewing as a whole. Our knowledge of its text depends on epigraphic finds from three sites: fragments of a text in Greek from Tamynae on Euboea give six lines (1-6) (Doyle, 1975; Lauffer, 1971, 168), while another Greek rendering of the rest of the chapter to line 13 (with an overlap at lines 5 and 6 with the Tamynae text) appears on fragments from Megalopolis in the Peloponnese (Mommsen, 1902, 1920-1921; Lauffer, 1971, 168) (Table 1). More recently the Latin archetype for lines 10-13 has been discovered in Aphrodisias and published with commentary by J.M. Reynolds (Reynolds, 1981; Reynolds, 1989, 287) (Table 2).

The bulk of the entries relate to prices (per Roman $\mathrm{lb}, 322.8 \mathrm{~g}$ ) of ready-washed raw wool from leading wool markets across the Empire. (The wool from Altinum in line 4 of the Tamynae text is not described as washed, but that may be a copyist's error.) They are listed in descending order of price, from 300 denarii for a pound of 'golden' wool from Mutina to 50 denarii for top and medium grade wool from any source, and 25 denarii for the cheapest. Atrebatic wool, tariffed at 200 denarii per lb, makes an appearance at the end of the list in line 13: it looks like a compiler's afterthought.

There are few surprises in the roster of wool centres; for most feature elsewhere in the Edict, in the catalogues of garments offered for sale or in the regulations for the wages of those preparing raw wool or finishing woven garments. The sheep farmers of the Po Valley take pride of place: they marketed their 'golden' and 'dark' (or 'longer stapled') wool through Mutina (lines 1-2) on the southern rim of the Po basin and Altinum (line 4) further north in the Veneto. The wool from both towns was highly regarded by earlier Roman writers (summarised by Lauffer, 1971, 264, 269; Frayn, 1984, 25), and a wealth of inscriptional evidence for many types of wool worker, together with finds of their tools, confirms the impression (Noè, 1974; Vicari, 2001, 37-47; Di Giuseppe, 2012).

Tarentum in Calabria (line 5) was another renowned Italian wool centre, to which Varro (RR II, 2, 18), Pliny (NH VIII, 190) and Columella (VI, 2, 3) devote considerable attention. The particular properties of Tarentine wool may stem from a policy of selective breeding for fleece improvement initiated by the first Greek colonists of the late eighth century BC and continued by their successors (Morel, 1978; Frayn, 1984, 23-24; Mele, 1997).

While the wool of Laodicea ad Lycum (line 6) in the Upper Maeander Valley of Phrygia is rated by the Edict's compilers as marginally inferior to that of the great Italian centres, a glance through the main textile chapters of the Edict immediately reveals the exceptionally wide range of the textile output of the town and its dominance of the imperial textile market (Ed D XIX, 25-27, 37-40, 63; XX, 4; XXI, 2; XXII, 19-20, 22). This may be no accident: P. Thonemann has argued that the industry was deliberately promoted by local magnates and that even the shepherds, normally at the bottom of the socio-economic ladder (Frayn, 1984, 69-70, 76-78), attained some prosperity (Thonemann, 2011, 185-190). 


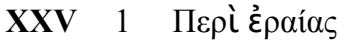

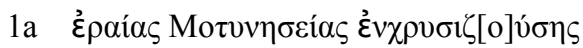

$$
\pi \varepsilon \pi \lambda v \mu \varepsilon \dot{\varepsilon}(v \eta \varsigma)
$$

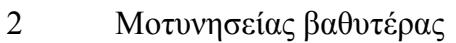

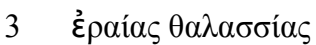

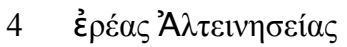

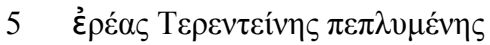

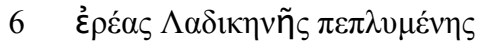

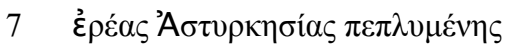

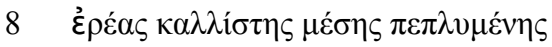

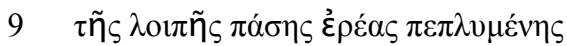

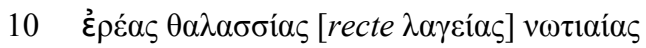

$11 \varepsilon \dot{\varepsilon} \rho \varepsilon_{\alpha \varsigma} \lambda \alpha \gamma \varepsilon i \alpha_{\alpha} \mu 1 \gamma \tilde{n} \varsigma$

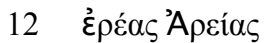

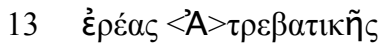

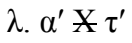

入. $\alpha^{\prime} \mathrm{X} \sigma^{\prime}$

入. $\alpha^{\prime} \mp v^{\prime}$

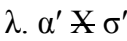

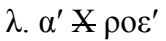

入. $\alpha^{\prime} \nsupseteq \rho v^{\prime}$

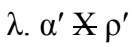

$\lambda . \alpha^{\prime} ¥ v^{\prime}$

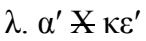

i. $\alpha^{\prime} \mathrm{X}\left[\sigma^{\prime}\right]$

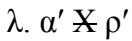

入. $\alpha^{\prime} \mathrm{X} \rho v^{\prime}$

入. $\alpha^{\prime} \mp \sigma^{\prime}$

Table 1. The Greek text of Chapter XXV of Diocletian's Edict (lines 1-6 from Tamynae, 5-13 from Megalopolis).
XXV 10 lanae leporinae dorsualis
po.unum X ducẹntis
11 1[a]ṇạe lẹporinae mixste
po.unum $\quad \mathrm{X}$ centum
12 [lanae Ari]ạnae
po. unum $\quad \mathrm{X}$ centum quinquagin(ta)
13 [lanae Atrebati]cae
po. unum $\mathrm{X}$ ducenț[i]s

Table 2. Chapter XXV, lines 10-13, of the Aphrodisias text of Diocletian's Edict (Reynolds 1989). 
At the other end of the Empire in north-west Gaul the civitas of the Atrebates on the Limes Belgicus (line 13) (and their neighbours, the Nervii [Ed D XIX, 44; 38, compare Caesar, $B G \mathrm{IV}, 3,2]$ ) attained Italian price levels for their wool: a writer of the Augustan Histories quotes Gallienus as saying that it props up the Empire (SHA, Gallienus 6, 6; Carus, Carinus et Numerianus 20, 6). The Astures in north-west Spain are a surprise inclusion (line 7): their wool is priced as above average in grade, but is virtually unrecorded in any other source (Alfaro Giner, 1984, 34 footnote 155). The sheep farmers of south-west Spain, however, according to Strabo made more profit from raw wool sales than by having it converted into clothing for the market (Strabo, III, 2, 6; Fear, 1992): the products of the Astures should perhaps be seen in this light. The paucity of archaeological evidence for the character of Spanish wool, however, has been noted by Carmen (Alfaro Giner, 2004; 2014).

Two general points about the wool list should be raised here. The first is an unresolved question: how are the place names in Chapter XXV to be interpreted? On the one hand there is the example of the Po Valley towns, Mutina and Altinum. There is so much epigraphic evidence for sheep rearing and wool processing on the Po plains (noted above) and the entries in the Edict are so detailed that one can reasonably assume that Mutina and Altinum were indeed the source of, and entrepôt for, the wool attributed to them in Chapter XXV. Yet a papyrus of AD 306 from Theadelphia in Egypt (P. Théad. 8) mentions Mutina sheep and rams, so Mutina also gave its name to a breed of sheep. The same may be said of Tarentum which lent its name to a famous breed of fine-woolled sheep prized by farmers in many parts of the Empire (Morel, 1978; Frayne, 1984, 28, 163-164, 166168; Wild, 1982), its fleece being protected traditionally with jackets (oves pellitae). While Mutina is a clothing manufacturing centre according to the Edict passim (29), Tarentum was not (only wool preparation is named: Edictum Diocletiani XXI, 2). Each case evidently has to be assessed in its own context (compare the views on long-distance wool sales of W. Jongmann [2000]).

The second point to note is that all the wools catalogued (taking the omission in line 4 to be a slip) are on sale ready-washed. At a local level complete wool fleeces 'in grease' would be traded, as for example at Dura-Europos (Baur, Rostovtzeff, Bellinger, 1933, 127 no. 252). Washing and cleansing a fleece of lanolin and detritus picked up in the field reduces its weight by up to $50 \%$ (Lovick, 2008), but at the same time enhances its value. Washing moreover was a preliminary to dyeing, as is attested at Pompeii, though not without academic controversy (Borgard, Puybaret, 2004, 47-60; Flohr, 2013; Monteix, 2013). Chapter XXV follows logically after Chapter XXIV, where prices for purple-dyed silk and wool are recorded and the wages of those spinning them (Lauffer, 1971, 166-168, 270-272).

The heading of Chapter XXV is 'On Wool'. But inserted among the entries for wool are prices for three fibre types which apparently were not sheeps' wool: lana marina, lana leporina and lana Ariana.

Lana marina (eraia thalassia in the Greek text of line 3), 'sea wool', at 400 denarii per $\mathrm{lb}$ is a third more expensive than the top-rated sheep's wool. Although there is still some hesitation among commentators (Lauffer, 1971, 264), there can now be little doubt that 'sea wool' is the silky filaments, $15-20 \mathrm{~cm}$ long, grown by the giant Mediterranean mussel Pinna nobilis to anchor itself to the sea bed. The Pinna nobilis, now a protected species, has been at the centre of a flourishing, if recherché, textile industry in the Gulf of Taranto and round Sardinia producing knitted and woven goods for a wealthy clientele since the Middle Ages. Felicitas Maeder, instigator of the Projekt Muschelseide in the 
Naturhistorisches Museum, Basel, has studied the history, technology and ethnography of pinna fibre and established its position as an important resource in antiquity (Maeder, 2002; Maeder, Hänggi, Wunderlin, 2004; www.muschelseide.ch/en.html). The first find of fibre to be identified as of Pinna, published in 1935, was made in a late Roman grave near Aquincum/Budapest (Nagy, 1935; Maeder, 2008); further Roman-period finds have been recognised recently in Pompeii (Schieck, Melillo, Mitschke, 2013; Albaladejò, Mitschke, 2013) and in the Rhineland (kind information from Felicitas Maeder). Not surprisingly, a dalmatic with hood made of 'sea silk' was in the same price range as versions of the same garment in silk according to Chapter XIX of the Edict.

In a recent article Antoinette Rast-Eicher has reviewed the evidence for the use of the hair of rabbit and hare, lana leporina (lines 10-11), in antiquity and the Early Middle Ages (Rast-Eicher, 2014, 44-49). A single Roman find has been recognised: a felt insole from Basel identified as of rabbit or hare fibre by A. Gansser-Burckhardt (Wild, 1970, 120 no. 97). It is possible, however, to distinguish the fibre of rabbit from that of hare under high-power light microscopy and Scanning Electron Microscopy. The latter has enabled Rast-Eicher to show that a seventh-century female grave at Kallnach-Bergweg (canton Basel) was furnished with a plain tabby textile woven with wool warp and rabbit-hair weft (Rast-Eicher, 2014, 44-49). Classical authors knew the difference between the two animals: Polybius, for example, writing before $120 \mathrm{BC}$, likens the rabbit of Corsica (kyniklos) to a small hare (lagos) and notes its propensity for digging burrows (Hist. XII, 2; compare Varro, RR III, 12, 4-6), while the Elder Pliny nearly three centuries later characterises the rabbits (cuniculi) of the Balearic Islands in a similar fashion (NH VIII, 81, 217-219). He comments, too, that the short staple length of pilus leporinus, rabbit or hare fibre, makes it difficult to convert into textile (NH VIII, 81, 219).

The Aphrodisias text of Chapter XXV, lines 10 and 11, records a price of 200 denarii per lb for lana leporina dorsualis, 'wool from the back of the rabbit (or hare)', and 100 denarii for 'mixed' lana leporina. (This probably means 'wool' taken from anywhere and everywhere on the coat rather than a blend of lana leporina and another fibre such as sheep's wool.) The Latin text, as J.M. Reynolds points out, incidentally corrects the unintelligible 'sea wool from the back', in line 11 of the Megalopolis Greek translation (Reynolds, 1981, 283-284).

Nonetheless the Edict's term lana leporina remains ambiguous: on balance rabbit's wool is to be preferred to hare's wool. In fact, rabbit's wool may have been a by-product of the farming of rabbits in Roman Italy, principally for the table (Varro, RR III, 12, 3, 312; Dohr, 1965, 41-42, 108-110); but shirts and tunics of lana leporina were not as expensive as those woven from conventional fine sheep's wool (Ed D XIX, 73a-73c).

We come at last to the problem of lana Ariana (line 12) (erea Areia in the Megalopolis text). Aria (Areia) is the name recorded by Greek and Roman geographers and historians for the province and region of Herat in present-day western Afghanistan (Strabo, XI, 11, 1; XV, 2, 1; XV, 2, 8; Pliny, NH VI, 61; VI, 93; Ptolemy, Geog. VI, 17 [Stevenson, 1932, 146-147, map 9; Pagani, 1990, maps XXIV, XXV]; Thomson, 1948, 292; Vogelsang, 2002, 120-122) (Fig. 1). Aria is also the name for the ancient predecessor of the modern city of Herat -Artacoana when it was under Achaemenid Persian rule, then Alexandria Arion after its conquest by Alexander in 329-327 BC (Arrian, Anab. Alex. III, 25, 5; Pliny, $N H$ VI, 61). The Hari Rud river which flows past Herat from the Hindu Kush westwards and then north into the desert also carried the name Aria or Arios (Arrian, Anab. Alex. VI, 6, 6). So lana Ariana, it appears, came from Afghanistan. 
Fig. 1. Map showing Aria in its geographical setting. Mountainous terrain is indicated in grey. (Drawn by J.P.Wild).

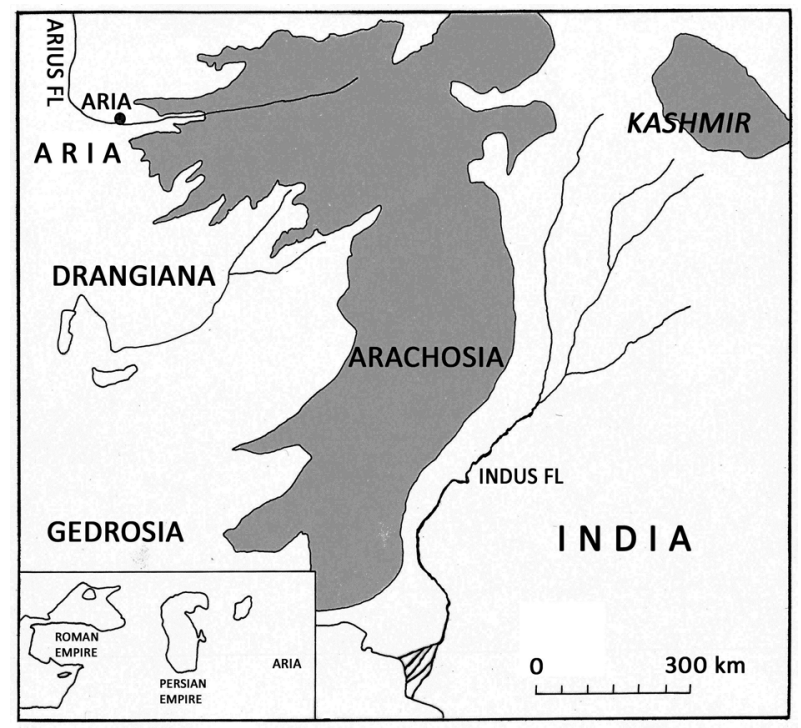

Some commentators are perplexed as to why and how such a commodity from far beyond the eastern Roman frontiers should have come to the attention of Diocletian's officials. (Silk from China, by contrast, raises no eyebrows.) Blümner declares lana Ariana to be 'unerklärt', wondering if it was something other than sheep's wool (Blümner, 1893, 168). Lauffer takes the same view (Lauffer, 1971, 272), while Frayn thinks of it as sheep's wool (Frayn, 1984, 143, 168). Morelli, perhaps under the influence of guesses by Blümner (and Lauffer), opts for cotton, ignoring the line so carefully drawn in the Edict between fibres of animal and of vegetable origin (Morelli, 2011, 221 footnote 34).

Joyce Reynolds, in discussing [lanae Ari] anae in the Aphrodisias text, accepts the connection with Aria and the Arii, citing Strabo, Pliny and Arrian (as above), and comments in addition: 'they certainly belong to sheep-rearing country, also notable for wild goat' (Reynolds, 1981, 284). The word 'goat' in this context will immediately prompt a textile archaeologist - particularly a sceptical one- to recall that fibres from the Kashmir goat have been claimed to be present in a handful of fine textiles from Classical antiquity. Before examining such claims and their significance, however, a few words about the Kashmir goat and its fibre are called for.

As its modern name implies, the archetypal Kashmir goat (capra hircus laniger) is reared in, and adapted to, the high-altitude pastures of the Himalayas and their severe climate. Its coat consists of an outer layer of long-stapled fibre varying from about $45 \mu \mathrm{m}$ to $150 \mu \mathrm{m}$ (mean $80 \mu \mathrm{m})$ in diameter and an all-important undercoat of shorter $(c .5 \mathrm{~cm}$ long) much finer fibres $(c .13 \mu \mathrm{m}$ to $19 \mu \mathrm{m}$ in diameter) which provide it with much needed insulation in the extreme temperatures (Rizvi, Ahmed, 2009, 12-13, 22-35; Wildman, 1954, 
106-112; Schaller, 1977; Ryder, 1987). The undercoat, termed pashm in Farsi, is the source material for the famous Kashmir shawls (today often called 'pashminas'), extremely fine and light fabrics which had established an international reputation by the sixteenth century (Rizvi, Ahmed, 2009, 142-239). In fact, goats of broadly Kashmir type have a wide distribution in mountainous terrain across Asia, and today 'cashmere' comes from north-east China, Mongolia, Tibet, Kyrgyzstan, Russia, Iran and Afghanistan (Rizvi, Ahmed, 2009, 23; Wildman, 1954, 106; Ryder, 1993, 41-43; www.acga.org.au/goatnotes/ G001.php). (Figures 2 and 3 show the cuticular scale patterning of modern cashmere fibres, from Italy and Iran respectively.) The undercoat is plucked or nowadays more commonly combed from the underbelly of the goat, and intrusive coarser fibres from the outer coat then picked out of the fibre mass by hand. A male goat yields $300 \mathrm{~g}$ to $500 \mathrm{~g}$ of unsorted, un-cleaned, pashm (Rizvi, Ahmed, 2009, 34-35).

Hair from humbler goats was spun (with difficulty) and woven commonly in the Roman world, but treated as a fibre of last resort, being extremely coarse and stiff. It was normally plied to improve the yarn's tensile strength, and its main use was for utilitarian items like sacks and tent cloth (Batcheller, 2001; Wild, Wild, 2000, 253, 271). Its undercoat is not of cashmere character. Mohair from the Turkish Angora goat has an obscure early history; but it is the result of selective breeding to create a uniform coat, and again is not to be confused with cashmere (Ryder, 1987).

The first analyst to consider the possibility that Kashmir (or cashmere) goat fibre was in use in the Roman world was Rodolphe Pfister in 1948, prompted by comment from his colleague M. Roehrich, who examined for him some extremely fine fibres in yarns from a group of textiles from Antinoe (Pfister, 1948, 61-63, 72), Egypt. The latter made up the distinctive costume of sleeved 'riding coat', shirt and gaiters worn by some presumed Sasanian cavalrymen resident at Antinoe in the late Roman period (Fluck, VogelsangEastwood, 2004, 21-22, 31-32). Roehrich's identification has been enthusiastically espoused by recent scholarship (Fluck, Vogelsang-Eastwood, 2004, 64, 124, 134, 142, 154, 166). It should be noted, moreover, that the research laboratory of the Monuments Historiques de Champs-sur-Marne confirmed the presence of cashmere in a pair of gaiters now in the Louvre (E29497) (Fluck, Vogelsang-Eastwood, 2004, 64 footnote 162).

Looking back at his publication of some exceptionally fine twills at Palmyra (L43 and L44) Pfister suspected that cashmere was present there, too, and when he reported on the textiles from Halabiyeh he claimed that several incorporated cashmere from Iran or Kashmir (Pfister, 1951, 44, 45, 58, 60, 67). Annemarie Stauffer in publishing the Palmyra corpus tabulated some sixteen textiles as containing cashmere fibre (Schmidt-Colinet, Stauffer, Al-Asad, 2000, 10-11, 52-53; Stauffer, 2013, 134, 135); the yarns however are regularly a cashmere and sheep's wool blend. In 1987, however, M.L. Ryder examined the wools of the two very fine Palmyra twills (L43 and L44 [Stauffer's catalogue no 420]) and pronounced them in his standard classification as wholly of true fine or fine generalised-medium sheep's wool (unpublished report prepared for M. Nockert, seen by courtesy of M.L. Ryder).

Yarns of sheep's wool and cashmere have also been claimed for some of the textiles from the At-Tar caves near Kerbala in Iraq which date to between the first and third centuries AD (Fibers and Textiles Laboratories, 1990, 69-92, 70 Table 1 [but note 'alpaca' in sample 13!]; idem, 1991). The analysis was undertaken by a commercial textile laboratory using a scanning electron microscope, but the criteria it adopted were purely visual, in 


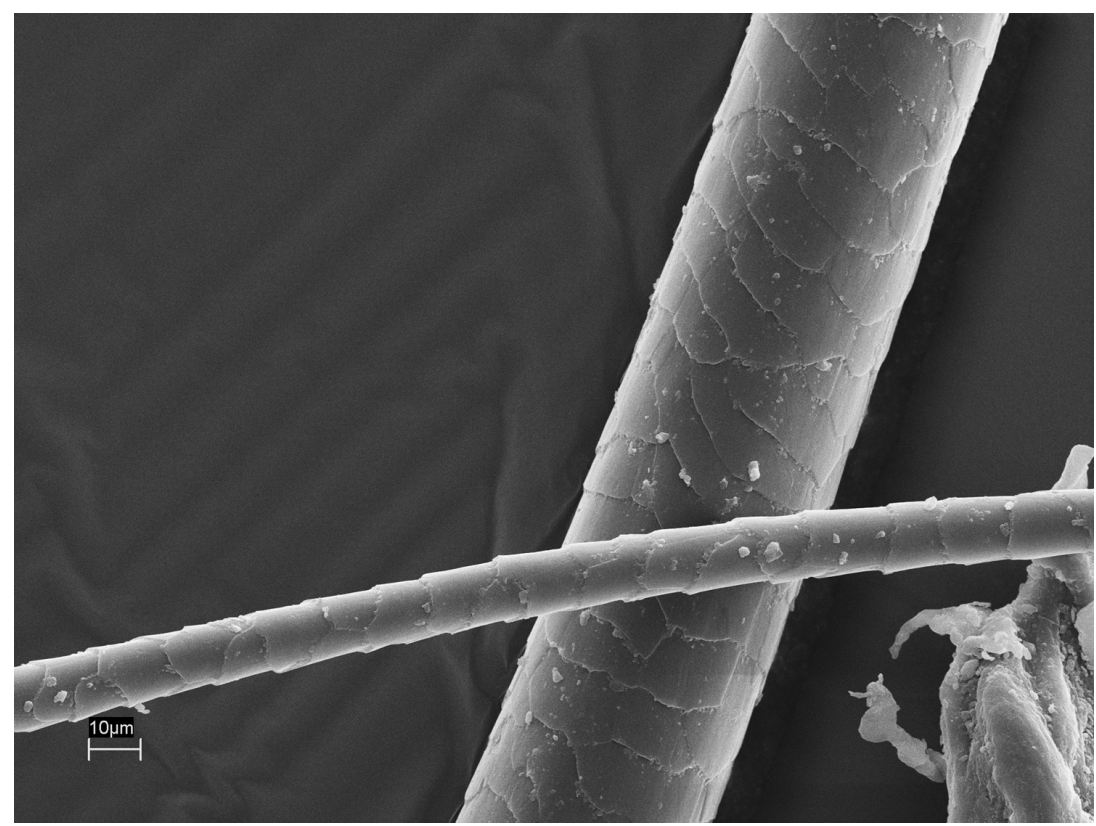

Fig. 2. Cashmere fibres (modern) from Biella, North Italy (scanning electron micrograph by courtesy of Antoinette Rast-Eicher, ArcheoTex).

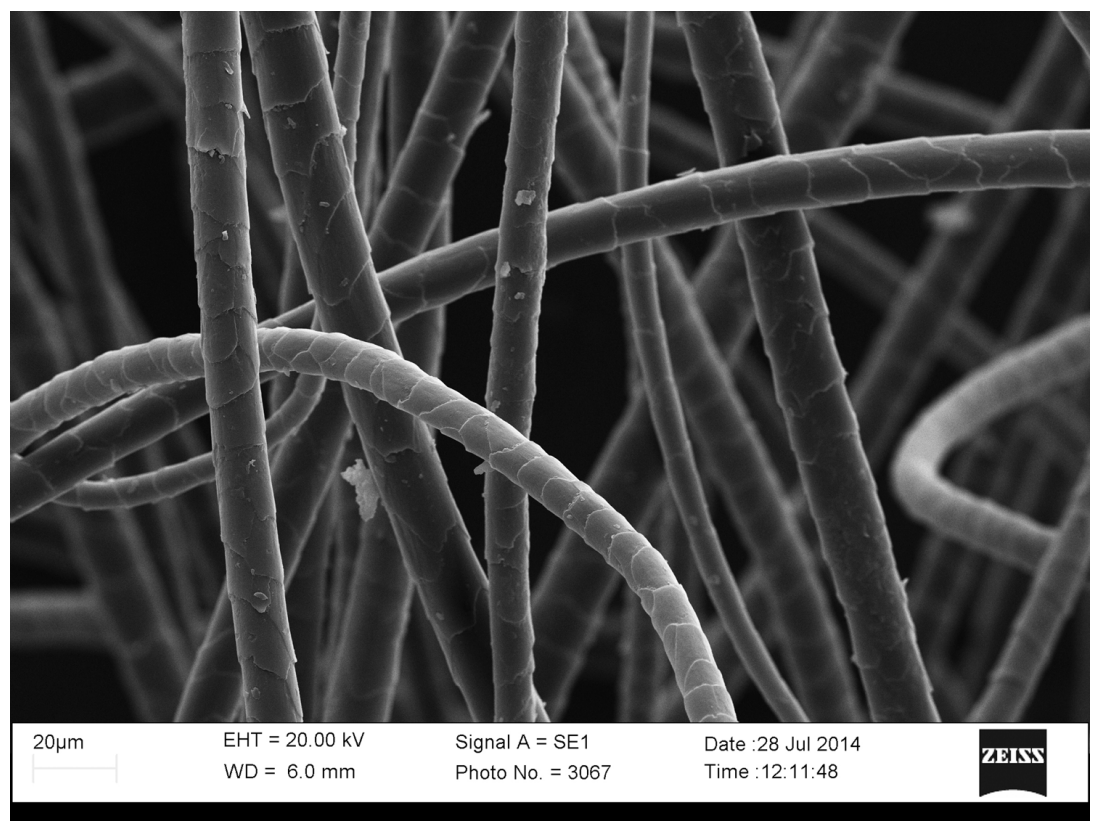

Fig. 3. Cashmere fibres (modern, brown) from Iran, EMPA collection (scanning electron micrograph by courtesy of Antoinette Rast-Eicher, ArcheoTex). 
principle the same as had been followed by Pfister and Roehrich fifty years before. More recently Christophe Moulherat has exploited to the full the power of scanning electron microscopy to argue that three textile fragments from the Greek colony of Lattes in south Gaul, dated archaeologically to c.475 BC, are of cashmere (Moulherat, Vial, 2000). The proximity of Palmyra, Halabiyeh and At-Tar to the traditional homelands of cashmere and the manifest Persian connection of the rider costumes at Antinoe- make the case for cashmere not implausible. Cashmere at Lattes, however, has a larger question-mark against it. (For even finer 'fine-wool' sheep's wool from Nymphaeum (Crimea) dating from c.450-400 BC see Ryder, 1983, 154-155.) One may ask, moreover, why the supposed cashmere fibre was blended so often with sheep's wool: was it adulteration, to eke out the supply of an expensive fibre or to reinforce the yarn?

Visual techniques including apparently objective criteria such as the measurement of cuticular scale height (Wildman, 1954, 112; Langley, Kennedy, 1981; Robson, Weedall, Harwood, 1989), are not, it seems, a satisfactory analytical tool in isolation; one can only hope that molecular techniques, applied to well-preserved textile samples, may one day remove the uncertainties.

The accuracy of the identification of the fibre -cashmere or fine sheep's wool- is in fact not the central issue in establishing what the Edict meant by lana Ariana. Rather, one may point to the very high quality of the fibre converted into yarn for the fine twills L43 and L44 at Palmyra, for example, and argue that this is what the Edict's compilers had in mind. It may or may not be cashmere (its price after all, at 150 denarii per $1 \mathrm{~b}$, was no more than that of wool from Laodicea). Moreover, it may or may not come from Aria/Afghanistan (for modern breeds in the region: Ryder, 1983, 270-271): the main point is that the compilers either thought so, or were accepting a common (but not strictly correct) designation that the public would comprehend.

It is evident that we have only just begun to understand the archaeology of the textile world in which the authors of the Edict lived and worked, and the information which they compressed into an apparently mundane catalogue. As Classical scholar and textile archaeologist, Carmen will appreciate, as much as the present writer, the pitfalls as well as the fascination of trying to reconcile textiles with texts in the search for a coherent story.

\section{ABBREVIATIONS}

Arrian, Anab. Alex.

Arrian, Anabasis Alexandri

Caesar, $B G$

Caesar, Bellum Gallicum

$E d D$

Pliny, $N H$

Edictum Diocletiani

P. Théad.

Pliny the Elder, Naturalis Historia

Polybius, Hist.

P. Jouguet, Papyrus de Théadelphie, Paris 1911

Ptolemy, Geog.

Polybius, Historiae

SHA

Ptolemy, Geographia

Varro, $R R$

Scriptores Historiae Augustae

Varro, de Re Rustica 


\section{BIBLIOGRAPHY}

ALBALADEJÒ, M., MITSCHKE, S. (2013): "Der Import exotischer Textilien nach Rom”, in: Tellenbach, M., Schulz, R., Wieczorek, A. (Eds.), Die Macht der Toga: Dresscode im römischen Weltreich, Mannheim, Reiss-Engelhorn-Museen, 137-143.

ALFARO GINER, C. (1984): Tejido y Cestería en la Península ibérica: Historia de su Técnica e Industrias desde la Prehistoria hasta la Romanización, Madrid, Instituto Español de Prehistoria, $350 \mathrm{p}$.

ALFARO GINER, C. (2004): "Late Roman textiles in the North of Spain ("Las Ermitas", Vitoria)", in: Maik, J. (Ed.), Priceless Invention of Humanity - Textiles, NESAT VIII, Acta Archaeologica Lodziensia 50/1, Łódź, Institute of Archaeology and Ethnology PAN, 27-31.

ALFARO GINER, C. (2014): "Wool fabrics from Arditurri Roman mines, Oiartzun (Basque country, Spain)”, in: Bergerbrant, S., Fossøy, S.H. (Eds.), A Stitch in Time: Essays in Honour of Lise Bender Jørgensen, Gothenburg, University of Gothenburg, 171-188.

BATCHELLER, J. (2001): "Goat-hair textiles from Karanis, Egypt", in: Walton Rogers, P., Bender Jørgensen, L., Rast-Eicher, A. (Eds.), The Roman Textile Industry and its Influence: A Birthday Tribute to John Peter Wild, Oxford, Oxbow, 38-47.

BAUR, P.V.C., ROSTOVTZEFF, M.I., BELLINGER, A.R. (Eds.) (1933): The Excavations at DuraEuropos: Preliminary Report of the Fourth Season of Work, October 1930 - March 1931, New Haven, University of Yale, $200 \mathrm{p}$.

BORGARD, P., PUYBARET, M-P. (2004): “Le travail de la laine au début de l'Empire: l'apport du modèle pompéien. Quels artisans? Quels équipments? Quelles techniques?” in: Alfaro Giner, C., Wild, J.P., Costa, B. (Eds.), Purpureae Vestes: Actas del 1 Symposium Internacional sobre Textiles y Tintes del Mediterráneo en época romana (Ibiza, 8 al 10 de noviembre, 2002), València, University of València, 47-60.

BRANDT, H. (2004): "Erneute Überlegungen zum Preisedikt Diokletians", in: Demandt, A., Goltz, A., Schlange-Schöningen, H. (Eds.), Diokletian und die Tetrarchie: Aspekte einer Zeitenwende, Berlin, De Gruyter, 47-55.

CORCORAN, S. (1996): The Empire of the Tetrarchs: Imperial Pronouncements and Government, $A D$ 284-324, Oxford, Oxford University Press, $440 \mathrm{p}$.

CRAWFORD, M.H. (2002): “Discovery, autopsy and progress: Diocletian's jigsaw puzzles”, in: Wiseman, T.P. (Ed.), Classics in Progress, London, Oxford University Press, 145-163.

CRAWFORD, M.H., REYNOLDS, J.M. (1975): "The publication of the Prices Edict: a new inscription from Aezani”, Journal of Roman Studies, 65, 160-163.

CRAWFORD, M.H., REYNOLDS, J.M. (1977): "The Aezani copy of the Prices Edict”, Zeitschrift für Papyrologie und Epigraphik, 26, 125-151.

CRAWFORD, M.H., REYNOLDS, J.M. (1979): "The Aezani copy of the Prices Edict", Zeitschrift für Papyrologie und Epigraphik, 34, 163-210.

DOHR, H. (1965): Die italienischen Gutshöfe nach den Schriften Catos und Varros, Köln, University of Köln, $165 \mathrm{p}$.

DOYLE, E.J. (1975): “Two new fragments of the Edict of Diocletian on Maximum Prices", Hesperia, 44, 77-97.

FRAYN, J.M. (1984): Sheep-Rearing and the Wool Trade in Italy during the Roman Period, Liverpool, Cairns, 208 p.

FLUCK, C., VOGELSANG-EASTWOOD, G. (Eds.) (2004): Riding Costume in Egypt: Origin and Appearance, Leiden, Brill, $416 \mathrm{p}$.

FLOHR, M. (2013): “The textile economy of Pompeii”, Journal of Roman Archaeology, 26, 53-78.

FEAR, A.T. (1992): "The Golden Sheep of Roman Andalusia", Agricultural History Review, 40, $151-155$. 
FIBERS \& TEXTILES LABORATORIES TORAY INDUSTRIES (1990): "Report on the analysis of textiles uncovered at the ancient Iraqi site", Al-Rāfidān, XI, 69-92.

FIBERS \& TEXTILES LABORATORIES TORAY INDUSTRIES (1991): "Report on the analysis of fibres of rush mats at At-Tar caves", Al-Rāfidān, XII, 163-164.

GIACCHERO, M. (1974): Edictum Diocletiani et Collegarum de Pretiis Rerum Venalium, Pubblicazione dell'Istituto di Storia Antica e Scienze Ausiliare dell'Università di Genova, VIII, Genova, University of Genova, Two volumes, 314, $180 \mathrm{p}$.

DI GIUSEPPE, H. (2012): "Lanifici e strumenti della produzione nell'Italia centro-meridionale", in: Busana, M.S., Basso, M.T. (Eds.), La Lana nella Cisalpina romana: Economia e Società. Studi in Onore di Stefania Pesavento Mattioli, Antenor Quaderni 27, Padua, University of Padua, 477-494.

JONGMAN, W. (2000): "Wool and the textile industry of Roman Italy: a working hypothesis", in: Lo Cascio, L. (Ed.), Mercati permanenti e Mercati periodici nel Mondo romano, Atti degli Incontri capresi di Storia dell'Economia antica, Capri, 13-15 ottobre 1997, Bari, Edipuglia, 187-197.

LANGLEY, K.D., KENNEDY, T.A.J. (1981): “The identification of speciality animal fibers”, Textile Research Journal, 51, 703-709.

LAUFFER, S. (1971): Diokletians Preisedikt, Berlin, De Gruyter, 361 p.

LOVICK, E. (2006): "Fleece to roving”, Journal for Weavers, Spinners and Dyers, 217, 16-17.

MAEDER, F. (2002): "The project sea-silk: rediscovery of an ancient textile material", Archaeological Textiles Newsletter, 35, 9-11.

MAEDER, F. (2008): "Sea-silk in Aquincum: first production proof in antiquity", in: Alfaro Giner, C., Karali, L. (Eds.), Vestidos, Textiles y Tintes: Estudios sobre la Producción de Bienes de Consumo en la Antigüedad, Purpureae Vestes II, València, University of València, 109-118.

MAEDER, F., HÄNGGI, A., WUNDERLIN, D. (Eds.) (2004): Bisso Marino: Fili d'Oro dal Fondo del Mare - Muschelseide: Goldene Fäden vom Meeresgrund, Basel, Museum der Kulturen, 128 p.

MEISSNER, B. (2000): "Über Zweck und Anlass von Diokletians Preisedikt", Historia, XLIX, 80-100.

MELE, A. (1997): "Allevamento ovino nell' antica Apulia e lavorazione della lana a Taranto", in: Moggi, M, Cordiano, G. (Eds.), Schiavi e Dipendenti nell'Ambito dell' 'oikos' e della 'famiglia', Atti del XXII Colloquio GIREA, Pontignano (Siena), 19-20 novembre 1995, Pisa, Edizioni ETS, 97-104.

MOMMSEN, T., BLÜMNER, H. (1983): Der Maximaltarif des Diocletian, Berlin, Georg Reimer, $206 \mathrm{p}$.

MONTEIX, N. (2013): “The apple of discord: fleece-washing in Pompeii's textile economy: a response to M.Flohr", Journal of Roman Archaeology, 26, 79-87.

MOREL, J.P. (1978): "La laine de Tarente”, Ktema, 3, 1978, 93-110.

MORELLI, F. (2004): “Tessuti e indumenti nel contesto economico tardoantico: i prezzi”, Antiquité Tardive, 12, 55-78.

MORELLI, F. (2011): "Dal Mar Rosso ad Alessandria: il verso (ma anche il recto) del "papiro di Muziris' (SB XVIII 13167)", Tyche, 26, 199-233.

MOULHERAT, C., VIAL, G. (2000): "Première attestation d'un tissu en laine de chèvre cachemire en Gaule", in: Cardon, D., Feugère, M. (Eds.), Archéologie des Textiles des Origines au Ve Siècle: Actes du Colloque de Lattes, oct. 1999, Montagnac, Éditions Monique Mergoil, 107-114.

NAGY, L. (1935): Múmia-Temetkézesek - Mumienbegräbnisse aus Aquincum, Dissertationes Pannonicae, 1, fasc.4, 18-20, 37-38.

NOÈ, E. (1974): "La produzione tessile nella Gallia Cisalpina in età romana", Rendiconti Istituto Lombardo di Scienze e Lettere, 108, 1974, 918-932.

PAGANI, L. (1990): Claudii Ptolemaei Cosmographia: Tabulae, Leicester, Magna Books.

PFISTER, R. (1948): "Le rôle d'Iran dans les textiles d'Antinoë”, Ars Islamica, 13/14, 46-74.

PFISTER, R. (1951): Textiles de Halabiyeh (Zenobia) découverts par le Service des Antiquités de la Syrie dans la Nécropole de Halabiyeh sur l'Euphrate, Paris, Paul Geuthner. 
RAST-EICHER, A. (2014): "Speciality fibres for special textiles", in: Bergerbrant, S., Fossøy, S.H. (Eds.), A Stitch in Time: Essays in Honour of Lise Bender Jørgensen, Gothenburg, University of Gothenburg, 43-62.

REYNOLDS, J.M. (1981): "Diocletian's Edict on Maximum Prices: the chapter on wool", Zeitschrift für Papyrologie und Epigraphik, 42, 283-284.

REYNOLDS, J.M. (1989): "The regulations of Diocletian", in: Roueché, C., Aphrodisias in Late Antiquity: the Late Roman and Byzantine Inscriptions including Texts from the Excavations at Aphrodisias conducted by Kenan T. Erim, London, Society for the Promotion of Roman Studies, 252-318.

RIZVI, J., AHMED, M. (2009): Pashmina: The Kashmir Shawl and Beyond, Mumbai, Marg Publications, $324 \mathrm{p}$.

ROBSON, D., WEEDALL, P.J., HARWOOD, R.J. (1989): “Cuticular scale measurements using image analysis techniques", Textile Research Journal, 59, 713-7.

RYDER, M.L. (1983): Sheep and Man, London, Duckworth, 846 p.

RYDER, M.L. (1987): Cashmere, Mohair and Other Luxury Animal Fibres for the Breeder and Spinner, Edinburgh, privately printed, $24 \mathrm{p}$.

RYDER, M.L. (1993): "The use of goat hair: an introductory historical review", Anthropozoologica, 17, 37-46.

SCHALLER, G.B. (1977): Mountain Monarchs: Wild Sheep and Goats of the Himalaya, Chicago, University of Chicago. (Reprinted 1989), 425 p.

SCHMIDT-COLINET, A., STAUFFER, A., AL-ASAD, K. (2000): Die Textilien aus Palmyra: Neue und Alte Funde, Mainz, Von Zabern, 201 p.

SCHIECK, A. PAETZ GEN, MELILLO, L., MITSCHKE, S. (2013): "Purpur, Gold und Seide: textile Vielfalt aus der Asche des Vesuvius", Antike Welt, 14 (1), 1-7.

STAUFFER, A. (2013): “Textile Luxusgüter aus dem Osten”, in: Tellenbach, M., Schultz, R., Wieczorek, A. (Eds.), Die Macht der Toga: Dresscode im römischen Weltreich, Mannheim, Reiss-Engelhorn-Museen, 132-136.

STEVENSON, E.L. (1932): Claudius Ptolemy: The Geography, New York, New York Public Library. (Reprinted 1991), $167 \mathrm{p}$.

THOMSON, J.O. (1948): History of Ancient Geography, Cambridge, Cambridge University Press, $427 \mathrm{p}$.

THONEMANN, P. (2011): The Maeander Valley: A Historical Geography from Antiquity to Byzantium, Cambridge, Cambridge University Press, $414 \mathrm{p}$.

VICARI, F. (2001): Produzione e Commercio dei Tessuti nell'Occidente romano, Oxford, Archaeopress, $123 \mathrm{p}$.

VOGELSANG, W. (2002): The Afghans, Oxford, Blackwell, 382 p.

WILD, J.P. (1970): Textile Manufacture in the Northern Roman Provinces, Cambridge, Cambridge University Press, $232 \mathrm{p}$.

WILD, J.P. (1982): "Wool production in Roman Britain", in: Miles, D. (Ed.), The Romano-British Countryside, British Archaeological Report 103, Oxford, British Archaeological Reports, 109-122.

WILD, J.P., WILD, F.C. (2000): “Textiles”, in: Sidebotham, S.E., Wendrich, W.Z. (Eds.), Berenike 1998: Report of the 1998 Excavation at Berenike and the Survey of the Egyptian Eastern Desert including Excavations in Wadi Kalalat, Leiden, Centre for Non-Western Studies, 251-274.

WILDMAN, A.B. (1954): The Microscopy of Animal Textile Fibres, Leeds, Wool Industries Research Association, 209 p. 
